\title{
Children's Reactions towards the Use of 'Child-Friendly' Learning Environments in an Obesity Prevention Health Education Program
}

\author{
Maziah Ahmad Marzuki ${ }^{1} \&$ Saemah Rahman ${ }^{2}$ \\ ${ }^{1}$ Department of Nursing, Faculty of Medicine, UKM Medical Centre, Universiti Kebangsaan Malaysia, Malaysia \\ ${ }^{2}$ Faculty of Education, Universiti Kebangsaan Malaysia, Malaysia \\ Correspondence: Saemah Rahman, Faculty of Education, Universiti Kebangsaan Malaysia, 43600 Bangi UKM, \\ Malaysia. Tel: 60-019-272-9290. E-mail:saemahukm@yahoo.com; saemah@ukm.edu.my
}

Received: October 27, 2014 Accepted: November 25, 2014 Online Published: February 12, 2015

doi:10.5539/ass.v11n5p235 URL: http://dx.doi.org/10.5539/ass.v11n5p235

\begin{abstract}
This article discusses the contribution of 'child-friendly' learning environments in an obesity prevention health education program for young children. The 'child-friendly' approach refers to a concept wherein the situation, place, as well as the activities conducted include elements that children like or enjoy and are suitable to their level. A total of 68 children between the ages of 3-6 years participated in the study. The program was conducted for 32 weeks at a kindergarten using a 'child-friendly' approach. Data regarding children's reactions towards the approach were collected using video recordings and anecdotal records from in-situ observation. The data were analyzed using ATLAS.ti. Research results show that the 'child-friendly' learning environment contributed four positive reactions from the children; $94.29 \%$ of the children were recorded to be 'happy', $90.02 \%$ were recorded to be 'excited', $98.59 \%$ showed 'acceptance' and $95.71 \%$ showed 'appreciation'. In conclusion, the research findings support the use of the 'child-friendly' approach in the teaching and learning process of children aged between 3-6 years as they are able to experience learning in an enjoyable manner thus motivating them to learn.
\end{abstract}

Keywords: child-friendly approach, obesity prevention, health education program, young children, preschool

\section{Introduction}

As an important awareness and prevention measure, children should be given health education instruction from an early age so that they are able to avert potential health problems in their future. For example, in the issue of obesity prevention, education should be conducted as early as possible as obesity cases are becoming increasingly worrisome; in Malaysia, the latest statistics on the issue of obesity show that there is an average of a one percent increase in child obesity cases every year (Malaysian Health Promotion Board, 2013).

Many children have unhealthy and unbalanced eating habits, indulging in sweets and carbonated drinks, and not consuming enough water, fruits and vegetables, as well as skipping breakfast. These eating habits have been found to have a positive relationship with the increase in adipose tissue content in the body which cause obesity problems among children and teenagers (Boutelle et al., 2002; Nicklas et al., 2003; Lin, Huang, \& French, 2004; Welsh et al., 2005; American Dietetic Association, 2006). It was also found that many children do not perform enough healthy physical activities such as exercise, house chores, and playing sports in an organized manner; statistics show that 76\% children between the ages of 3-6 years lack physical activity (Hillary et al., 2005; Taveras et al., 2006; Lumeng et al., 2006). Similiarly, Ridgers et al. (2014) found that overweight children engaged in less percentage of vigorous physical activities during school recess.

Therefore, there is a need for children to be exposed to health and obesity prevention education at an early age so that they are able to inculcate healthy habits which can be carried on into adulthood. The question is what is the best way to educate these young children? Health and obesity prevention education are essentially challenging, as the nature of health education is against that of children who are more inclined to play. After all, every moment of a child's life is filled with play (Puteh \& Ali, 2012). Therefore, in order to ensure a more effective and sustainable learning process for young children, a fun and enjoyable learning environment is necessary to capture their minds and emotions, attract their interest, and increase their motivation to learn as well as to persuade them to practice what they learn in their daily lives. 
Educational psychology literature suggests the application of psychological aspects in the education of children, stressing on behaviour and mental processes, especially in the understanding of effective teaching and learning concepts (Santrock, 2011; Ormrod, 2014). The application of educational psychology in instructing children influences their minds, making it possible to persuade them to change their behaviour, in this case, making them choose healthy habits over bad ones. Sallis \& Glanz (2009) suggest that the inculcation of healthy habits among children should be done using various ways that can motivate the child to learn freely and create awareness about the importance of healthy habits in their daily lives.

There is great importance in understanding the children's world and how certain elements in it can be controlled during the teaching and learning process so as to make communication with them easier and they are able to learn without being forced to. It is believed that the use of 'child-friendly' approaches will make this possible. 'Child-friendly' means a situation, place, or activity that children enjoy and is suited to their level (Jo, Penny \& Allison, 2007); this shows us the necessity of providing an attractive and interesting learning environment for children as a way to stimulate active-learning in their learning process. Therefore, the 'child-friendly' approach can be used as a strategy to promote healthy lifestyles among children (Sallis \& Glanz, 2009).

Jo, Penny \& Allison (2007) conducted a study to learn children's opinions on the hospital environment aspect known as the care area; she found that a 'child-friendly' environment can be achieved by understanding children's nature and outlook and fulfilling their needs and expectations. A study by Broberg, Kytaa, and Fagerholm (2013) on the development of 'child-friendly' learning environments found that the 'child-friendly' concept consisted of two main criteria i.e. i) children are able to move freely without depending on adults and ii) children are able to control their environment independently and without force. Besides that, John (2004) observed a Hollywood program which was produced using the 'child-friendly' concept i.e. using children's cartoon illustrations, animated pictures, child-oriented language, story-telling concepts and play-based activities. The research found that the Hollywood program was able to attract the interest and attention of children, making them continue watching and learning from the program. It can then be concluded that the application of 'child-friendly' approaches is able to produce an enjoyable learning process for children and can motivate them to learn without being forced to do so.

This paper is a discussion of the children's reactions towards a health education program that uses a 'child-friendly' approach. Within this context, the researcher will discern whether the health education program fulfilled its aim of being 'child-friendly' i.e. the program was enjoyable and meaningful for the children, and that the children were not stressed or bored in following the schedule of the program

\section{Method}

A health education program for children between the ages of 3-6 years with the aim of obesity-prevention was developed using a 'child-friendly' approach through the incorporation of play-based and casual activities. The research involved 68 (86.08\% response rate) children with the consent of their parents, after obtaining permission to conduct research from the PPUKM ethics committee (Project code No. GUP-301-2011). The sample distribution according to age and gender is shown in Table 1.

Table 1. Demographic data of the children $(\mathrm{N}=68)$

\begin{tabular}{|c|c|c|c|}
\hline \multirow{2}{*}{ Demographic data of the children } & \multicolumn{2}{|c|}{ Gender } & \multirow{2}{*}{ Total $\mathrm{n}(\%)$} \\
\hline & Male $\mathrm{n}(\%)$ & Female $\mathrm{n}(\%)$ & \\
\hline \multicolumn{4}{|l|}{ Age } \\
\hline - 3 years old & $7(10.29)$ & $8(11.76)$ & $15(22.06)$ \\
\hline - 4 years old & $12(17.65)$ & $6(8.82)$ & $18(26.47)$ \\
\hline - 5 years old & $7(10.29)$ & $11(16.18)$ & $18(26.47)$ \\
\hline-6 years old & $7(10.29)$ & $10(14.71)$ & $17(25.0)$ \\
\hline
\end{tabular}

The health education program was conducted for an hour each session, three times a week (Tuesday, Wednesday, and Thursday) for 32 weeks at a kindergarten in Malaysia. Two main components were focused on in the program i.e. the eating component and the physical activity component. Various activities were offered during the program.

The program was started with a 5-10 minute teaching and learning slot using 'child-friendly' video, animated cartoon images, colourful learning notes, and teaching was delivered using the storytelling mode. This was followed by a 5 minute slot for stretching then a 30-45 minute slot for aerobics using a 'child-friendly' exercise 
video. The children were given a choice of doing the aerobics guided by an animated cartoon video or the " 1 Student 1 Sport' official video, or by playing games such as 'main getah', bowling, jigsaw puzzles, Lego, and the food pyramid game (for example, categorizing food into their respective food groups, arranging food groups in the food pyramid and collecting food according to their categories). The children were also given prizes, praise, and credit (using a star chart) according to the scheduled activities as a way to increase their motivation, happiness, and enjoyment.

In the duration of the study, the researcher played the role of facilitator and observer, listening, evaluating, and watching the children's behaviour from any distance and recording the changes in behaviour. The researcher was assisted by an assistant researcher who took notes, made observations, made video recordings, and took pictures. The data collected from video recordings, pictures, and anecdotal records from the observation were then analyzed inductively based on the research questions. The data were transcribed, watched, and read to glean general information and was then coded using ATLAS.ti version 7.0. The analysis process was conducted by developing codes or themes; the 'type of text or visual image or type of material' was then inserted into these themes and the frequency of themes was calculated.

\section{Results}

The research findings are reported based on children's reaction data obtained from the observation of their behaviour, video recording of their activities, pictures and in-situ anecdotal records. The focus of the observation is on the reaction shown by children towards the learning process. Analysis of the data found that four themes can be formed in illustrating the children's reactions towards the ongoing learning process i.e. happy, excited, acceptance, and appreciation.

i) The 'happy' reaction

The children's 'happy' reaction refers to behaviour such as cheering, laughing, and smiling while talking to their peers during the activity. An example of a showcase of this reaction is when a child smiles and laughs while saying:

"Yeah yeah yeah, aerobik ini ...suka-suka (Yay yay yay, aerobics... I like)"

"Haaa ya... nak yang ini...ini.... ya cikgu...(Haaa yes... I want this one... this one... yes teacher...)"

The child is seen to be smiling, his/her finger pointing to the screen while happily talking to his/her friends, and says "Yeahhhhh..., senaman ni... (Yay... this exercise...)" when the video for the day is shown on the screen. The children also clap their hands and cheer "Yahooooo" when the activity of their choice is used as the activity of the day. Data analysis shoes that $94.24 \%(n=64)$ of the children showed this response.

\section{ii) The 'excited' reaction}

The children show that they are 'excited' by making choices about the activities, asking a lot of questions, laughing, competing to answer questions, telling stories, and impatiently waiting for the program to start. $90.02 \%$ $(n=61)$ of the children showed this response. For example, the children showed impatience in waiting for the program to start:

"Cikgu cepatlah ..bila nak mula ni? (Teacher, quick... when are we going to start?)" "Ha, tengok tu cikgu datang, best best... (Hey look, the teacher is coming... great)"

The children also showed a behaviour of asking many questions about the activity that will be conducted:

"Cikgu nak ajar apa hari ini??? (teacher, what are you teaching us today?)"

"Cikgu, esok belajar apa? (Teacher, what are we learning tomorrow?)"

The children impatiently and competitively tried to answer questions, saying "Saya.. saya.. saya nak jawab ... (Me... me... I want to answer the question)". Besides that, they were seen telling stories about their activities and eating routines at home:

"Cikgu hari ni saya sarapan pagi... saya makan roti... (Teacher, I had breakfast today... I ate some bread...)"

"Cikgu, cikgu saya makan biskut ... (Teacher, teacher, I ate biscuits...)"

"Cikgu, cikgu, cikgu saya minum susu dalam kereta (Teacher, teacher, teacher, I had milk in the car"

"Hari ini saya minum susu kotak cikgu ... (I had milk in a carton today, teacher...)"

"Cikgu, cikgu, cikgu, saya bawa air kosong hari ni (Teacher, teacher, teacher, I brought water today)" 
Lastly, the children were seen to be excited when making decisions about which activity they wanted to have on the particular day:

"Cikgu, hari ni buat senam aerobik ya cikgu? (Teacher, can we do aerobics today?)"

"Cikgu, esok kita main getah boleh???... Yeahhhhh... (Teacher, can we play 'main getah' tomorrow?... Yay...)"

"Cikgu, buka lah senaman gangnam style transformer??... Yeahhhhh (Teacher, play the gangnam style transformer exercise?... Yay....)"

"Ha tengok cikgu buka video senaman kartun tu... best nya.jom buat (Hey look, the teacher is playing the cartoon exercise video... Great. Let's do it." (simultaneously pointing to the screen, which is showing an animated cartoon video, and smiling).

iii) The 'acceptance' reaction

The children showed 'acceptance' where they were able to accept and understand the instruction by showing spontaneous reactions such as clapping their hands, cheering, singing along to the music, and also through their facial expressions and their dialogues. 98.59\% $(n=67)$ of the children showed this reaction. An example of this reaction is when the children talked about the healthy activities they do and the healthy food they eat at home. They also excitedly answered the questions the teacher posed them. Their acceptance of the educational content instructed to them can be seen through behaviours such as: "Eeeeei, takut nya... (Oh how scary...) (while showing a frightened reaction, frightened facial expression, hugging a friend)"; "Oh tidak, tak mau jadi macam tu (Oh no, I don't want to become like that) (while showing a surprised reaction, surprised facial reaction, hugging a friend)". The children were also ready to conduct the activities such as aerobic exercise (accompanied by an animated cartoon exercise video) while singing: "Roti, roti, roti, roti ... yeahhhh ... roti menang (Bread, bread, bread, bread... yay.. the bread won" (while cheering and clapping at a video depicting a food fight between healthy food and fast food). They even asked for the activities to be repeated:

"Cikgu, pasang la semula video tu.. best la.. (Teacher, please replay the video again... it was so fun"

"Cikgu .... nak tengok semula video tu, nak lagi .. nak lagi (Teacher... I want to watch the video again... I want more, I want more)"

"Cikgu, sikit je belajar hari ini??? alaaaa ... (Teacher, we're learning so little today? Oh no...)"

iv) The 'appreciation' reaction

The children showed appreciation for the teaching and learning session by saying 'thank you', waving their hands, kissing their teacher's hand, and smiling. 95.71\% $(\mathrm{n}=65)$ children showed this reaction. Examples of these reactions are:

"Terima kasih cikgu ... (Thank you, teacher)"

"Cikgu, cikgu ...nak salam ...terima kasih cikgu.. (Teacher, teacher... I want to shake hands with you... thank you, teacher)."

The children said "Byeee" while waving and smiling at the teacher. They also shook hands (or bersalam) and kissing the teacher's hands as a sign of respect and appreciation.

\section{Discussions}

The health education program developed using the 'child-friendly' approach in this research was found to have elicited four positive reactions among the children; these code were themed 'happy', 'excited', 'acceptance', and 'appreciation'. Even though various teaching and learning methods for young children could have been utilized in the health awareness program, the use of the 'child-friendly' approach was the main focus of this research. The education of children, especially in terms of inculcating health awareness, is unquestionably challenging; children are naturally inclined towards play and tend to focus less on structured daily lessons (Puteh \& Ali, 2012). The approach of understand the children's world and environment is a tactic to capture their hearts and minds and consequently influence positive changes on their behaviour so they are able to deeply appreciate and understand knowledge about healthy activities and eating habits. In the opinion of Salia \& Glanz (2009), the children's world must be understood and comprehended so that the teaching and learning process can be experienced without any sort of force. 
This also agrees with a concept in Urie Bronfenbrenner's model as well as Carl Roger's learning model. According to Bronfenbrenner (1994), the growth and development of a child is influenced by his environment, wherein it can be manipulated by providing a 'child-friendly' atmosphere which will positively influence his learning. The main focus of this model centres on the child; it is the environment around him that can influence his growth and development, as well his daily learning (Bronfenbrenner, 1994). On the other hand, Carl Roger's learning concept focuses on the strategy and approaches that need to be planned and arranged according to the child emotional needs and development (Santrock, 2011). The application of this learning approach develops strong self-motivation to learn without force; children also experience effective learning processes through the use of enjoyable 'child-friendly' methods which elicit positive reactions among children in accepting learning.

Besides that, research shows that a majority of the children (more than $85 \%$ ) showed positive reactions i.e. i) happy, ii) excited, iii) acceptance, and iv) appreciation throughout the length of the health education program. This situation shows that the children's motivation increased, they are able to learn without force, and they are becoming more aware about healthy habits in their daily routine. The 'child-friendly' method used in this research was able to produced children who are active and motivated to learn. It also established better communication with the children. The children also showed sustained effort to learn without being forced to and they also began to learn interactively amongst themselves. According to Salia \& Glanz (2009), we must provide an attractive learning environment for children to stimulate them as well as a strategy to promote and encourage healthy lifestyles among children (Vickerius \& Sandberg, 2006). Therefore, the 'child-friendly' approach made the learning environment more attractive and fun for the children.

The activities that were provided in the program were mostly play-based. It was found that $64(94.24 \%)$ of the children were happy while performing the activities scheduled for them; this shows that the integration of play in early childhood learning is necessary and of pivotal importance in their learning environment This is supported by Miller \& Almon (2009); Bodrova \& Leong (2010), and Puteh \& Ali (2012) who state that a child's natural phenomenon is to learn through play, exploring nature, conducting experiments, and trial and error. Through play, children actively learn to understand the issues in their environment in an enjoyable manner; they become more confident, are able to develop their identities, build motivation, and amass knowledge from a very young age.

When children are motivated to learn, all activities can be performed easily. This is in agreement with the opinion that motivation is a process that arouses and sustains active effort; it compels an individual to change his behaviour, needs, interest, or activity, and is a stimulus for acting towards a cause or goal (O'Donnell, Reeve \& Smith 2012). The positive reactions shown by the children in this research demonstrate how the 'child-friendly' concept initiated their motivation to learn. Research results found that the reaction with the highest frequency was that coded using the theme "acceptance" i.e. $98.59 \%(n=67)$ where a majority of the children showed spontaneous reactions of singing while performing aerobic exercise (accompanied by an animated cartoon exercise video) and cheering and clapping while watching a video.

Therefore, data showed that the 'child-friendly' approach presented a positive contribution to the children's learning process. This was evidenced by how the children did not show any signs of being stressed, tired, or bored of the scheduled activities; instead, they experienced learning in a joyful manner. The results of this research are in line with previous research done regarding the 'child-friendly' concept John (2004), Nordstrom (2004), Woolcock (2008) dan Broberg, Kytaa, and Fagerholm (2013). All these research show that the usage of the 'child-friendly' concept successfully changed the aspect of children's learning environment and it is this attractive learning environment that becomes a stimulus to create happiness and positive reactions in a child's learning environment as well as his daily life.

\section{Conclusions}

Research results clearly show that the use of 'child-friendly' approaches in an obesity prevention health education program positively contributed to an enjoyable learning environment for the children. The children showed four positive reactions towards this approach i.e. i) happy, ii) excited, iii) acceptance, and iv) appreciation. Therefore, the usage of a 'child-friendly' approach remains the main focus of effective teaching and learning methods for young children. The research suggests that 'child-friendly' approaches should be integrated into the teaching and learning process, especially for younger children i.e. those aged between 3-6 years. This is because the 'child-friendly' approach has been found to capture the minds and influence the behaviour of children, enabling them to learn in a motivated manner and without force. They are also able to accept the fun learning experience which consequently increases their motivation to learn continuously. In the 
context of this research, children were also found to actively perform healthy lifestyles by establishing healthy habits in their daily routines.

\section{References}

American Dietetic Association. (2006). Childhood overweight evidence analysis project. Retrieved August 15, 2012, from http://www.adaevidencelibrary.com/topic.cfm?cat_1046

Bodrova, E., \& Leong, D. J. (2010). Curriculum and play in early child development. Retrieved August 15, 2012, from http://www.child-encyclopedia.com/documents/Bodrova-LeongANGxp.pdf

Boutelle, K., Neumark-Sztainer, D., Story, M., \& Resnick, M. (2002). Weight control behaviors among obese, overweight, and non-overweight adolescents. J. Pediatr. Psychol., 27, 531-540. http://dx.doi.org/10.1093/ jpepsy/27.6.531

Broberg, A., Kytta, M., \& Fagerholm, N. (2013). Child-friendly urban structures: Bullerby revisited. Journal of Environmental Psychology, 35, 110-120. http://dx.doi.org/10.1016/j.jenvp.2013.06.001

Bronfenbrenner, U. (1994). Ecological models of human development. International Encyclopedia of Education, $3(2), 1643-1647$.

Hillary, L., Burdette, M. D., Robert, L., \& Whitaker, M. D. (2005). A national study of neighborhood safety, outdoor play, television viewing and obesity in preschool children. Pediatrics, 116(3), 657-662. http://dx.doi.org/10.1542/peds.2004-2443.

Jo, B., Penny, C., \& Allison, J. (2007). Space to care: An ESRC funded project exploring children's perceptions and experiences of hospital space, research briefing. Sheffield, Swindon: University of Sheffield ESRC.

John, H. (2004). Make your teaching child-friendly. Retrieved April 1, 2013, from http://www.guardian.co.uk/ education/2004/nov/19/tefl4

Lin, B. H., Huang, C. L., \& French, S. A. (2004). Factors associated with women's and children's body mass indices by income status. Int. J. Obes. Relat. Metab. Disord., 28, 536-542.

Lumeng, J. C., Rahnama, S., Appugliese, D., Kaciroti, N., \& Bradley, R. H. (2006). Television exposure and overweight risk in preschoolers. Arch Pediatr. Adolesc. Med., 160, 417-422. http://dx.doi.org/10.1001/ archpedi.160.4.417.

Malaysian Health Promotion Board. (2013). Statistik obesiti di Malaysia. Kuala Lumpur: Ministry of Health, Malaysia.

Miller, E., \& Almon, J. (2009). Crisis in kindergarten: Summary and recommendations of why children need to play in school. A report from Alliance. Retrieved August 15, 2012, from http://earlychildhoodcolorado.org/ inc/uploads/Crisis_in_Kindergarten.pdf

Nicklas, T. A., Yang, S. J., Baranowski, T., Zakeri, I., \& Berenson, G. (2003). Eating patterns and obesity in children: The Bogalusa heart study. Am. J. Prev. Med., 25, 9-16. http://dx.doi.org/10.1016/S07493797(03)00098-9.

Nordstrom, M. (2004). The reflection of environment in chidren's notions of child-friendly environments. Special Issue $18^{\text {th }}$ IAPS-Conference, 18, 64-73.

O’Donnell, A. M., Reeve, J. M., \& Smith, J. K. (2012). Educational psychology: Reflection for action. United States of America: John Wiley \& Sons, Inc.

Ormrod, J. E. (2014). Educational psychology: Developing learners (8th ed.). Pennsylvania: Pearson Education.

Puteh, S. N., \& Ali, A. (2012). Persepsi guru terhadap penggunaan kurikulum berasaskan bermain bagi aspek perkembangan bahasa \& literasi murid prasekolah. Jurnal Pendidikan Bahasa Melayu, 2(1), 141-159.

Ridgers, N. D., Saint-Maurice, P, F., Welk, G. J., Siahpush, M., \& Huberty, L. J. (2014). Non-overweight and overweight children's physical activity during school recess. Health Education Journal, 73, 129-136. http://dx.doi.org/10.1177/0017896912471032

Sallis, J. F., \& Glanz, K. (2009). The role of built environments in physical activity, eating, and obesity in childhood. Future Child, 16, 89-108.

Santrock, J. W. (2011). Educational psychology (5th ed.). University of Texas, New York: McGraw-Hill International Edition.

Taveras, E. M., Sandora, T. J., Shih, M.-C. S., Ross-Degnan, D., Goldmann, D. A., \& Gillman, M. W. (2006). 
The association of television and video viewing with fast food intake by preschool-age children. Obesity, 14(11), 2034-2041. http://dx.doi.org/10.1038/oby.2006.238

Vickerius, M., \& Sandberg, A. (2006). The significance of play and the environment around play. Early Child Development and Care, 176, 207-217. http://dx.doi.org/10.1080/0300443042000319430

Welsh, J. A., Cogswell, M. E., Rogers, S., Rockett, H., Mei, Z., \& Grummer-Strawn, L. M. (2005). Overweight among low-income preschool children associated with the consumption of sweet drinks: Missouri, 1999 2002. Pediatrics, 115(2), 223-229. http://dx.doi.org/10.1542/peds.2004-1148.

Woolcock, G., \& Steele, W. (2008). Towards the development of an indicators framework for a child-friendly community: Literature review. Urban Research Program for the NSW Commission for Children and Young People, Griffith University.

\section{Copyrights}

Copyright for this article is retained by the author(s), with first publication rights granted to the journal.

This is an open-access article distributed under the terms and conditions of the Creative Commons Attribution license (http://creativecommons.org/licenses/by/3.0/). 